\title{
THEORETICAL STUDIES OF ICE SEGREGATION IN SOIL
}

\author{
By Kiyoshi Arakawa \\ (Department of Physics, Hokkaido University, Sapporo, Japan)
}

\begin{abstract}
The mathematical theory of heat conduction is applied to the analysis of ice segregation processes in soil. A diffusion equation is first employed for the flow of soil moisture. Two new quantities, the rate of ice segregation, $\sigma$, and the segregation efficiency, $E$, are introduced. The first is the rate of ice growth measured as mass per area per time. The latter is defined as $E=\sigma L /\left(K_{1} \partial T_{1} / \partial x-K_{2} \partial T_{2} / \partial x\right)$, where $L$ is the latent heat of fusion of ice, $T_{\mathrm{I}}$ and $K_{\mathrm{I}}$ are the temperature and thermal conductivity of frozen soil, and $T_{2}$ and $K_{2}$ are the temperature and thermal conductivity of unfrozen soil. Three types of soil freezing can be classified in terms of $E$ : freezing of non-frost-susceptible soil $(E=0)$, perfect segregation $(E=\mathrm{I})$ and imperfect segregation $(0<E<\mathrm{I})$. Finally, the mathematical boundary conditions at an advancing frost line are obtained in freezing, frost-susceptible soil $(E \neq 0)$. Two parameters related to the structure of soil are pointed out, which seem to be valid criteria of frost susceptibility. The amount of frost-heaving is derived under special conditions.
\end{abstract}

RÉsumé. Études théoriques de ségrégation de glace dans les sols. La théorie mathématique de conduction calorifique est appliquée à l'analyse de processus de ségrégation de glace dans les sols. Une équation de diffusion est d'abord employée pour l'écoulement de l'humidité des sols. Les nouvelles quantités, la vitesse de ségrégation de la glace $\sigma$, et l'efficience de ségrégation $E$, sont introduites. La première est la vitesse de croissance de la glace mesurée en masse par surface par temps. La dernière est définie par $E=\sigma L /\left(K_{1} \partial T_{1} / \partial x-K_{2} \partial T_{2} / \partial x\right)$, où $L$ est la chaleur latente de fusion de la glace, $T_{1}$ et $K_{1}$ sont la température et la conductivité thermique du sol gelé, $T_{2}$ et $K_{2}$ la température et la conductivité thermique du sol non gelé. En utilisant $E$, trois types de gel du sol peuvent se distinguer: gel de sol non susceptible au gel $(E=0)$, ségrégation parfaite $(E=\mathrm{I})$ et ségrégation imparfaite $(0<E<\mathrm{I})$. Finalement les conditions mathématiques aux limites et la ligne de gel en progression sont obtenues pour un sol susceptible au gel en train de geler $(E \neq 0)$. Deux paramètres en relation avec la structure du sol sont mis en valeur; ils semblent constituer des critères valides pour la susceptibilité au gel. La valeur du soulèvement dû au gel en est dérivée dans des conditions spéciales.

Zusammenfassung. Theoretische Untersuchung der Eisabsonderung im Boden. Die mathematische Theorie der Wärmeleitung wird auf die Analyse von Eisabsonderungsprozessen im Boden angewandt. Zuerst wird eine Diffusionsgleichung für den Fluss der Bodenfeuchtigkeit angesetzt. Zwei neue Grössen, nämlich die Geschwindigkeit der Eisabsonderung $\sigma$ und der Absonderungsgrad $E$, werden eingeführt. Die erste ist die Geschwindigkeit des Eiswachstums, gemessen in Masse pro Fläche und Zeit. Die zweite ist definiert durch $E=\sigma L /\left(K_{1} \partial T_{1} / \partial x-K_{2} \partial T_{2} / \partial x\right)$, wobei $L$ die latente Wärme des Schmelzens von Eis, $T_{1}$ und $K_{1}$ die Temperatur und die Wärmeleitzahl von gefrorenem Boden, $T_{2}$ und $K_{2}$ die entsprechenden Werte für ungefrorenen Boden bedeuten. Mit Hilfe von $E$ können drei Typen von Bodenfrost unterschieden werden: Gefrieren von nicht-frostempfänglichem Boden $(E=0)$, vollkommene Absonderung $(E=\mathrm{I})$ und unvollkommene Absonderung $(0<E<\mathrm{I})$. Schliesslich werden die mathematischen Grenzbedingungen für eine vorrückende Frostlinie in gefrierendem, frostempfänglichem Boden $(E \neq 0)$ hergeleitet. Zwei Parameter für die Bodenstruktur, die wirksame Kriterien für die Frostempfänglichkeit zu sein scheinen, werden herausgestellt. Das Ausmass der Frosthebung wird unter bestimmten Bedingungen ermittelt.

\section{INTRODUGTION}

The first mathematical investigation of ice segregation was reported by Fujiwhara (I 924), who suggested that ice segregation is a heat-conduction problem when particular boundary conditions exist at a stationary frost line. Ruckli (I950) and Redozubov (I962) reported theoretical investigations based on the mathematical theory of heat conduction. However, they did not use reasonable boundary conditions for the flow of heat or of soil moisture.

This paper gives an account of an attempt to study the various factors related to the process of ice segregation from a unified viewpoint which is based on the mathematical theory of heat conduction. This method involves the conditions of soil-moisture flow at a frost line. In the following it is assumed that the problem is one of unidirectional heat conduction.

\section{Perfect Ige Segregation}

There is a great deal of literature which proves the applicability of a diffusion equation for the flow of soil moisture (Macey, I940; Staple and Lehane, I954; Klute and others, I956; 
Gardner and Hillel, r 962). In this paper the following equation is used for the flow of moisture in soil:

$$
\frac{\partial M}{\partial t}=\frac{\partial}{\partial x}\left(D \frac{\partial M}{\partial x}\right)
$$

where $M=$ moisture content in $\mathrm{g} . / \mathrm{cm} .^{3}, t=$ time, $x=$ coordinate, and $D=$ diffusion coefficient.

Next, we introduce a physical quantity to specify the process of ice segregation. This is called the "ice segregation rate" in dimensions of mass per unit area per unit time. In the growth of segregated ice in the ground the equations of continuity of water flow and of heat flow at a stationary frost line are as follows:

and

$$
\begin{aligned}
\sigma & =D \frac{\partial M}{\partial x} \\
K_{\mathrm{I}} \frac{\partial T_{1}}{\partial x} & =K_{2} \frac{\partial T_{2}}{\partial x}+\sigma L,
\end{aligned}
$$

where $\sigma=$ ice segregation rate, $K_{\mathrm{I}}=$ thermal conductivity of ice, $K_{2}=$ thermal conductivity of unfrozen soil, $T_{\mathrm{x}}=$ temperature of ice, $T_{2}=$ temperature of soil, and $L=$ latent heat of fusion of ice.

The parameter $\sigma$ may be eliminated from these equations, giving

$$
K_{\mathrm{r}} \frac{\partial \mathcal{T}_{\mathrm{I}}}{\partial x}=K_{2} \frac{\partial T_{2}}{\partial x}+L D \frac{\partial M}{\partial x} .
$$

Equation (4) is a continuity equation and, at the same time, a heat balance equation.

With regard to the freezing temperature of the soil, there is also another boundary condition:

$$
T_{1}=T_{2} .
$$

There are many observations which confirm that the temperature of soil freezing is not equal to the ice point, but it depends on the moisture content as well as the soil structure (Bouyoucos, I92 I ; Beskow, [1935]; Higashi, 1958). The new boundary condition can be expressed by the equation

$$
\tau_{\mathrm{I}}=T_{2}=f(M),
$$

where $f(M)$ is a function of the moisture content, $M$. There has been no detailed experimental observation of the function $f(M)$. However, it is very likely that the freezing-temperature curves for different types of soils, as measured by Beskow ([r 935$]$ ), give a fairly good estimate of $f(M)$. It should be noted that the function $f(M)$ implicitly involves the effects of the soil structure. From a thermodynamic point of view, the hydrostatic pressure of the soil moisture is also involved as a variable in equation (6). Equations (4) and (6) state the necessary boundary conditions for ice segregation where a frost line is fixed in position. This is called perfect segregation.

\section{IMPERFEGT SEGREGATION}

When a frost line moves through the soil and ice segregation occurs at the same time, the process is called imperfect segregation. In this case, the heat-balance equation at an advancing frost line is, from a macroscopic point of view,

$$
\kappa_{\mathrm{I}} \frac{\partial T_{\mathrm{I}}}{\partial x}-K_{2} \frac{\partial T_{2}}{\partial x}=\sigma L+L M \frac{d X}{d t},
$$

where $K_{\mathrm{I}}=$ thermal conductivity of frozen soil, $K_{2}=$ thermal conductivity of unfrozen soil, $T_{1}=$ temperature of frozen soil, $T_{2}=$ temperature of unfrozen soil, $\sigma=$ ice segrega- 
tion rate, $L=$ latent heat of fusion of ice, $M=$ moisture content in $\mathrm{g} . / \mathrm{cm} .3$, and $d X / d t=$ rate of penetration of the frost line.

Again, the equation of continuity in this case is

$$
\sigma=D \frac{\partial M}{\partial x}
$$

The other boundary condition must again be assumed:

$$
T_{\mathrm{I}}=T_{2}=f(M) \text {. }
$$

The three boundary conditions given in equations (6), (7) and (8) are all useful in solving the present problem but there is still an unknown parameter, $\sigma$. In order to eliminate $\sigma$, it is necessary to introduce a new concept of segregation efficiency, $E$, which is defined as follows:

$$
E=\sigma L\left(/ K_{\mathrm{I}} \frac{\partial T_{\mathrm{I}}}{\partial x}-K_{2} \frac{\partial T_{2}}{\partial x}\right)
$$

Using equation (9), the following equations can be derived from equations (7) and (8):

and

$$
K_{1} \frac{\partial T_{1}}{\partial x}-K_{2} \frac{\partial T_{2}}{\partial x}=\frac{L M}{\mathrm{I}-E} \frac{d X}{d t}
$$

$$
\frac{E}{L}\left(K_{\mathrm{I}} \frac{\partial T_{\mathrm{I}}}{\partial x}-K_{2} \frac{\partial T_{2}}{\partial x}\right)=D \frac{\partial M}{\partial x} .
$$

These are equations of heat balance (equation (I0)) and continuity of water flow (equation (II)). When $E$ is known, equations (IO), (II) and (6) provide the necessary boundary conditions for imperfect segregation.

\section{Segregation Efficiency}

Segregation efficiency is introduced above without thorough examination. Although the elimination of the unknown parameter, $\sigma$, in equations (7) and (8) has been done primarily for mathematical convenience, its original definition in equation (9) has reasonable physical meaning.

Early in I929 Taber ( 1929 ) reported that "the chief factors controlling ice segregation and excessive heaving are: size of soil particle, amount of water available, size and percentage of voids, and rate of cooling". Taber's results have been confirmed by many investigators (Beskow, [1935]; Penner, 1960). However, it has been impossible to obtain positive mathematical definition of those controlling factors. It is reasonable to assume that two physical quantities are directly related to ice segregation: the ice-segregation rate and the segregation efficiency. As has been shown in the previous section, the first quantity is eliminated when perfect segregation occurs. With regard to the latter quantity, the following relationship is assumed from Taber's experimental results:

$$
E=F\left\{M,\left(K_{\mathrm{I}} \frac{\partial T_{1}}{\partial x}-K_{2} \frac{\partial T_{2}}{\partial x}\right)\right\}
$$

where $F$ is a function of the moisture content, $M$, and the difference of the heat flow $\left(K_{\mathrm{I}} \partial T_{\mathrm{I}} / \partial x-K_{2} \partial T_{2} / \partial x\right)$ at a frost line. This equation must be determined empirically and therefore the function $F$ includes all of the parameters related to the structure of the individual soil.

In general, when segregation efficiency is used, macroscopic freezing processes can be classified into three types: freezing of non-frost-susceptible soil $(E=0)$, perfect segregation $(E=\mathrm{I})$ and imperfect segregation $(\mathrm{o}<E<\mathrm{I})$. For each of these three types, there is a particular set of boundary conditions. To select these boundary conditions, it is first necessary to find the numerical value of $E$. If the ice-segregation rate is used first instead of segregation 
efficiency, the selection of boundary conditions is impossible, because specifying the icesegregation rate does not discriminate between perfect and imperfect segregation.

Preliminary determination of a numerical value for $E$ is possible when the initial frost line is located between frozen and unfrozen soil. However, when a frost line is located at the surface of soil which is exposed to cold air, an additional condition is necessary to determine the segregation efficiency. This particular condition is the rate of heat loss, $\dot{Q}$, at the surface. Then, $K_{\mathrm{I}} \frac{\partial T_{\mathrm{I}}}{\partial x}$ in equation (12) should be replaced by $\dot{Q}$. In the classical problems studied

by Stefan and Neumann (Carslaw and Jaeger, I959, p. 282-96), there is no such additional initial condition. This is a particular characteristic of the present problem, the freezing of frost-susceptible soil.

The numerical value of $E$ in freezing soil varies with time. Therefore, in the calculations the segregation efficiency $E$ should be recognized as an additional variable to the temperature, $T_{1}$ and $T_{2}$, and the moisture content, $M$.

\section{Moving Boundaries}

When a frost line penetrates into frost-susceptible soil, there are two moving boundaries that should be taken into consideration: the frost line and the upper surface of the frozen soil which is exposed to the air. The upward movement of the latter is called frost-heaving. Under natural conditions the rate of frost-heaving is usually not larger than the rate of frost penetration, over comparatively long periods of time. However, under laboratory conditions it is not unusual for the rate of frost-heaving to exceed the rate of frost penetration over short periods of time in extremely frost-susceptible soil.

Higashi (1958) and Penner (I960) reported experimental results concerning the relation between the rate of heaving and the rate of frost penetration. Penner (1960) stated in his paper that "The findings by Higashi are in complete contradiction to results obtained by all other research workers to date." However, it seems very reasonable that there is in general no definite relationship between these two quantities. This point of view can be verified by Ōno's (196o) experimental work on which he reported as follows:

"The difficulty encountered in the experiment intended to observe the preventive effect of a substance against frost-heaving is the freezing of the sample to the walls of the container, since in case it happens, the frost-heaving will be restrained owing to large friction, so that one is likely to mistake the restraint for the preventive action of the substance in question. With the intention of reducing the friction, we tried to line the box with teflon, polyethylene, or aluminium film and in some cases used a box made of glass or vinyl plastic in place of a wooden one, but they all proved to have very little effect. With these boxes no frost-heaving but only 'frost-depression', as we may call it, was observed."

Experimental work reported by Corte (I962) and Uhlmann and others (I964) suggests that the rate of segregation is the fundamental physical quantity which specifies the process of segregation, but quantities such as the rate of frost-heaving or the displacement of the whole body of the frozen part cannot be defined.

Under particular conditions, however, it may be reasonable to assume the following relation between the rate of frost-heaving and the rate of ice segregation:

$$
\frac{d h}{d t}=\frac{\sigma}{\rho_{i}}
$$

where $d h / d t=$ frost-heaving rate, $\sigma=$ ice-segregation rate, and $\rho_{i}=$ density of ice. 
From equations (8) and ( 13 ), the total amount of frost-heaving can then be expressed by the following equation:

$$
h=\frac{\mathrm{I}}{\rho_{i}} \int_{0}^{t}\left(D \frac{\partial M}{\partial x}\right)_{x=X} d t .
$$

Because of the assumptions, equation (14) shows the maximum amount of frost-heaving under given conditions.

\section{Rhythmic BAnding}

One significant approximation made in the previous equations concerns the moisture content, $M$, on the right-hand sides of equations (7) and (Io). These two equations imply that all the moisture freezes when a frost line passes over. But this is not correct, because experimental observation on unfrozen soil moisture in apparently frozen soil has been reported (Bouyoucos, I92I ; Beskow, [1935]). Therefore, it is reasonable to replace $M$ by $M \gamma$, where $\gamma$ is less than unity. At present it is not easy to determine a definite relationship between $\gamma$ and the other variables. Corresponding to the introduction of $\gamma$, it may be expected that there is a gradual liberation of latent heat of unfrozen soil moisture in frozen soil above the advancing frost line. If these two factors are satisfactorily taken into account by the equations (which may be recognized as a second-order approximation), the special phenomenon of "rhythmic banding" (Taber, I930) can be understood by a mathematical analysis.

\section{Frost Susceptibility}

It has been suggested in the previous section that in equations (6) and (12) there are particular parameters related to physical properties of soil or the structure of soil. From the present macroscopic point of view, it is impossible to identify precisely the important soilstructure parameters. However, there are various kinds of substances other than soil which manifest ice segregation (Hardy, I926; Moran, I926; Asahina, 1956). The parameters referred to above may be very useful, because they can also be applied to the other substances as well as to soil.

\section{Discussion and Conclusion}

The formulations described are largely independent of recent works on frost-heaving, in which rate of frost-heaving is recognized as the fundamental quantity to be examined. At present it is evident that two quantities, (I) the rate of ice segregation and (2) the segregation efficiency, are fundamentally important for understanding the processes of ice segregation. Up to the present time, no attempt has been made to use these two quantities in both experimental and theoretical investigations. It therefore seems desirable to verify these boundary conditions by future experiments.

In the present treatment, no particular mechanism for ice segregation need be assumed in order to determine the rate of ice segregation. However, it will be necessary to examine the segregation efficiency from a microscopic point of view. Recent work reported by Uhlmann and others (I964) may be recognized as the first attempt based on the microscopic approach, when segregation efficiency is assumed to be unity.

Frost-susceptibility criteria and depth of frost penetration are two important problems which have been investigated for many years as separate topics (Linell, i96o). However, the present formulation shows that they can be examined in terms of the same physical principles; in fact, they are inseparable.

MS. received 5 March 1965 and in revised form 2 June 1965 


\section{REFERENCES}

Asahina, E. 1956. The freezing process of the plant cell. Contributions from the Institute of Low Temperature Science, No. 10, p. 83-126.

Beskow, G. [1935.] Tjälbildningen och tjällyftningen med särskild hänsyn till vägar och järnvägar. Sveriges Geologiska Undersökning. Avhandlingar och Uppsatser. Ser. C, No. 375, Årsbok 26, No. 3, 1932. [English translation: Soil freezing and frost heaving with special application to roads and railroads.... Translated by $\mathcal{J}$. O. Osterberg. Evanston, Illinois, Technological Institute, Northwestern University, I947.

Bouyoucos, G. J. 1921. A new classification of the soil moisture. Soil Science, Vol. I I, No. I, p. 33-47.

Carslaw, H. S., and Jaeger, J. C. 1959. Conduction of heat in solids. Second edition. Oxford, Clarendon Press.

Corte, A. E. 1962. Vertical migration of particles in front of a moving freezing plane. Journal of Geophysical Research, Vol. 67, No. 3, p. I085-9o.

Fujiwhara, S. 1924. On ice columns in soil. Journal of the Meteorological Society of Japan, Ser. 2, Vol. 2, No. 2, p. $55^{-58}$.

Gardner, W. R., and Hillel, D. I. 1962. The relation of external evaporative condition to the drying of soils. Fournal of Geophysical Research, Vol. 67, No. I1, p. 4319-25.

Hardy, W. B. 1926. A microscopic study of the freezing of gel. Proceedings of the Royal Society, Ser. A, Vol. I 1 2, No. 760 , p. $47-6 \mathrm{r}$.

Higashi, A. I958. Experimental study of frost heaving. U.S. Snow, Ice and Permafrost Research Establishment. Report 45.

Klute, A., and others. 1956. The application of the diffusivity concept to soil moisture movement, by A. Klute, R. R. Bruce and M. B. Russel. VIe Congrès International de la Science du Sol (Paris). Rapports, Vol. B, p. 345-52.

Linell, K. A. I96o. Frost action and permafrost. (In Woods, K. B., ed. Highway engineering handbook. New York, McGraw-Hill, p. I3-1-13-35.)

Macey, H. H. I940. Clay-water relationship. Proceedings of the Physical Society (London), Vol. 52, Pt. 5, p. $625-56$.

Moran, T. 1926. The freezing of gelatin gel. Proceedings of the Royal Society, Ser. A, Vol. I 12, No. 760 , p. 30-46.

Ōno, T. ig6o. Studies on frost-heaving and anti-heaving agents. Teion-kagaku [Low Temperature Science], Ser. A, Vol. 19, p. 225-29.

Penner, E. I96o. The importance of freezing rate in frost action in soils. Proceedings of the American Society for Testing Materials, Vol. 6o, p. $1 \mathrm{I}_{5} \mathrm{I}-65$.

Redozubov, D. V. 1962. O zadache Stepana pri lineynom nachal'nom raspredelenii temperatury v polubeskonechnoye srede [The Stefan's problem for a linear initial temperature distribution in a semi-infinite medium]. Izvestiya Akademii Nauk SSSR. Seriya Geofizicheskaya [Newes of the Academy of Sciences of the U.S.S.R. Geophysical Series], 1962, No. 4, p. 558-61. [Translation in Bulletin of the Academy of Sciences of the U.S.S.R. Geophysical Series, 1962, No. 4, p. $364-66$.]

Ruckli, R. 1950. Der Frost im Baugrund. Wien, Springer-Verlag.

Staple, W. J., and Lehane, J. J. r 954. Movement of moisture in unsaturated soils. Canadian Fournal of Agricultural Science, Vol. 34 , No. 4, p. 329-42.

Taber, S. r 929 . Frost heaving. Fournal of Geology, Vol. 37, No. 5, p. 428-6r.

Taber, S. 1930. The mechanics of frost heaving. Fournal of Geology, Vol. 38, No. 4, p. 303-1 7.

Uhlmann, D. R., and others. I 964 . Interaction between particles and a solid-liquid interface, by D. R. Uhlmann, B. Chalmers and K. A. Jackson. Journal of Applied Physics, Vol. 35, No. 10, p. 2986-93. 